\title{
Teachers' professional development: An analysis of the use of Professional Development Plans in a Dutch school
}

Citation for published version (APA):

Janssen, S., Kreijns, K., Theo, B., Stijnen, S., \& Vermeulen, M. (2012). Teachers' professional development: An analysis of the use of Professional Development Plans in a Dutch school. Professional Development in Education, 38(3), 453-469. https://doi.org/10.1080/19415257.2011.635307

DOI:

10.1080/19415257.2011.635307

Document status and date:

Published: 01/01/2012

Document Version:

Peer reviewed version

Please check the document version of this publication:

- A submitted manuscript is the version of the article upon submission and before peer-review. There can be important differences between the submitted version and the official published version of record. People interested in the research are advised to contact the author for the final version of the publication, or visit the DOI to the publisher's website.

- The final author version and the galley proof are versions of the publication after peer review.

- The final published version features the final layout of the paper including the volume, issue and page numbers.

Link to publication

\section{General rights}

Copyright and moral rights for the publications made accessible in the public portal are retained by the authors and/or other copyright owners and it is a condition of accessing publications that users recognise and abide by the legal requirements associated with these rights.

- Users may download and print one copy of any publication from the public portal for the purpose of private study or research.

- You may not further distribute the material or use it for any profit-making activity or commercial gain

- You may freely distribute the URL identifying the publication in the public portal.

If the publication is distributed under the terms of Article 25fa of the Dutch Copyright Act, indicated by the "Taverne" license above, please follow below link for the End User Agreement:

https://www.ou.nl/taverne-agreement

Take down policy

If you believe that this document breaches copyright please contact us at:

pure-support@ou.nl

providing details and we will investigate your claim.

Downloaded from https://research.ou.nl/ on date: 26 Apr. 2023 
This article was downloaded by: [University of Maastricht]

On: 07 December 2012, At: 02: 38

Publisher: Routledge

Informa Ltd Registered in England and Wales Registered Number: 1072954 Registered

office: Mortimer House, 37-41 Mortimer Street, London W1T 3J H, UK

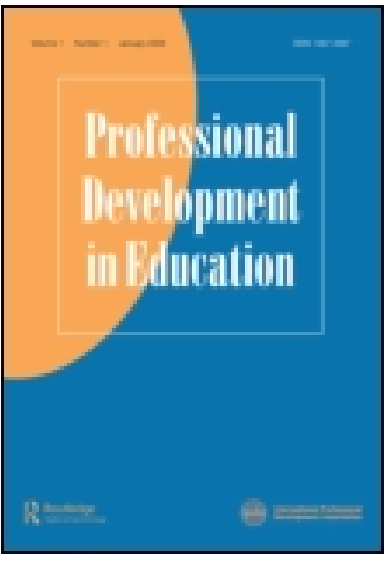

\title{
Professional Development in Education
}

Publication details, including instructions for authors and subscription information:

http:// www.tandfonline.com/loi/ rjie20

\section{Teachers' professional development: an analysis of the use of Professional Development Plans in a Dutch school}

\author{
S. J anssen ${ }^{a}$, K. Kreijns ${ }^{a}$, T. Bastiaens ${ }^{a}$, S. Stijnen ${ }^{a} \&$ M. \\ Vermeulen $^{\mathrm{a}}$ \\ a Ruud de Moor Centre (RDMC), Open University of the \\ Netherlands, P. O. Box 2960, 6401, DL, Heerlen, The Netherlands \\ Version of record first published: 30 J an 2012.
}

To cite this article: S. J anssen, K. Kreijns, T. Bastiaens, S. Stijnen \& M. Vermeulen (2012): Teachers' professional development: an analysis of the use of Professional Development Plans in a Dutch school, Professional Development in Education, 38:3, 453-469

To link to this article: http:// dx.doi.org/ 10.1080/ 19415257.2011.635307

\section{PLEASE SCROLL DOWN FOR ARTICLE}

Full terms and conditions of use: http://www.tandfonline.com/page/terms-andconditions

This article may be used for research, teaching, and private study purposes. Any substantial or systematic reproduction, redistribution, reselling, loan, sub-licensing, systematic supply, or distribution in any form to anyone is expressly forbidden.

The publisher does not give any warranty express or implied or make any representation that the contents will be complete or accurate or up to date. The accuracy of any instructions, formulae, and drug doses should be independently verified with primary sources. The publisher shall not be liable for any loss, actions, claims, proceedings, demand, or costs or damages whatsoever or howsoever caused arising directly or indirectly in connection with or arising out of the use of this material. 


\title{
Teachers' professional development: an analysis of the use of Professional Development Plans in a Dutch school
}

\author{
S. Janssen*, K. Kreijns, T. Bastiaens, S. Stijnen and M. Vermeulen \\ Ruud de Moor Centre (RDMC), Open University of the Netherlands, P.O. Box 2960, 6401 \\ $D L$, Heerlen, The Netherlands
}

(Received 26 January 2011; final version received 22 October 2011)

\begin{abstract}
Professional development of teachers has become an essential condition in today's knowledge-based society to sustain the quality of teaching. Therefore, the Dutch government promotes this now professional development. As a result, Professional Development Plans (PDPs) are now increasingly used to stimulate and support the professional development of teachers. A PDP is used to encourage teachers' professional development and structure their development path in terms of learning goals and plans of action. However, it cannot be taken for granted that teachers will formulate high-quality PDPs on their own. Previous research suggests that guidance is important in supporting teachers' development. This study examined the effects of guidance on the quality of PDPs. An experimental group of Dutch teachers from a school for secondary vocational education was offered a series of workshops whereas the control group did not have such guidance. Both groups had to fill out a simple structured PDP. To determine the quality of the PDPs, an assessment tool was developed. The results suggest that guided teachers are more capable of identifying their strengths and in formulating learning goals. The guided teachers' PDPs also showed more consistency. No differences were found regarding the action plans which teachers described.
\end{abstract}

Keywords: professional development; professional development plan; selfregulation; guidance; support; teachers

\section{Introduction}

In the Netherlands, the educational labor market is challenged by quantitative as well as qualitative shortages (Ministry of Education, Culture, and Science 2007). Therefore, the Dutch government introduced the Education Professions Act in 2004 (wet op Beroepen In het Onderwijs, BIO). According to this law, teachers are obligated to maintain and develop their professional abilities and record the process in a portfolio. On the basis of this law, the Dutch foundation for the quality of teachers (Stichting Beroepskwaliteit Leraren, SBL) defined a list of competences that are needed in the teacher profession. These competences serve as a frame of reference for the professional development of teachers (Ministry of Education, Culture and Science 2005). Moreover, the government argued that to achieve high-quality education schools need a solid personnel policy. This policy is

\footnotetext{
*Corresponding author. Email: sandra.janssen@ou.nl
} 